\title{
Sweat Equity: Student scholarships in Aotearoa New Zealand's Universities
}

\author{
Max Soar ${ }^{1,2}$, Lucy Stewart ${ }^{3}$, Sylvia Nissen $^{4}$, Sereana Naepi $^{5}$, Tara McAllister ${ }^{2 *}$
}

${ }^{1}$ Centre for Science in Society, Victoria University of Wellington, Wellington, New Zealand, 0000-0001-7509-7861

${ }^{2}$ Te Pūnaha Matatini, University of Auckland, Auckland, New Zealand, 0000-0002-9228-8421

${ }^{3}$ Toha Foundry Ltd, Wellington, New Zealand 0000-0001-7352-3329

${ }^{4}$ Department of Environmental Management, Lincoln University, Christchurch, New Zealand, 0000-0001-52369860

${ }^{5}$ Department of Sociology, University of Auckland, Auckland, New Zealand, 0000-0002-6067-9014

\begin{abstract}
This paper responds to calls from past and present students to increase the value of postgraduate scholarships in Aotearoa New Zealand. Here we provide context for understanding the scholarship landscape in Aotearoa, including how scholarships are understood in relation to dominant neoliberal framings of higher education and persistent inequities within the sector. We present data which provides insight into the current inequities in Summer, Masters and $\mathrm{PhD}$ scholarship values. The average value of PhD scholarships has remained stagnant between 2011 and 2019 resulting in the average being $\$ 11,238$ less than the Living Wage in 2019. We show that the average length of time full-time $\mathrm{PhD}$ students take to complete their doctorates exceeds the three-year tenure of scholarships. We argue the status-quo of low scholarships, supplemented by postgraduate 'sweat', excludes people from participating in postgraduate education, preventing them and their communities from realising the public benefits that such an education can produce. We suggest that these inadequacies could be addressed through 1) raising Summer, Masters and PhD scholarships to the living wage; 2) extending tenure of PhD scholarships; and 3) reinstating the postgraduate student allowance.
\end{abstract}

Keywords: postgraduate, scholarships, inequity, $\mathrm{PhD}$ 


\section{Sweat Equity: Student scholarships in Aotearoa New Zealand's Universities}

\section{Introduction}

Increasingly there are calls from the research sector that postgraduate scholarships are insufficient for the increased cost of living in Aotearoa New Zealand. Through open letters (Morton, 2021), petitions (Hopkins, 2020; O'Connor \& Hyde, 2021), surveys (Naepi, 2021; Simpson, 2021), and the news media (Guesgen, 2021; 'Time for Leadership in Science', 2021) researchers are consistently highlighting the inadequacy of scholarships and the urgent need to build stable career paths for emerging researchers. This paper provides a context for understanding the postgraduate research scholarship landscape in Aotearoa, including how postgraduate research scholarships are understood in relation to dominant neoliberal framings of higher education and persistent inequities within the sector.

The progression to postgraduate research studies is often presented as linear: a Summer scholarship and an Honours and/or research Masters progresses into a Doctor of Philosophy (PhD), which is configured as the 'gateway' into a research career. All eight universities in Aotearoa award summer scholarships, research Masters degrees, and PhDs. Summer scholarships are small, funded, and supervised projects that introduce scholars (usually undergraduates) to primary research over university holidays. Research Masters degrees often involve some combination of coursework and a significant self-directed research component and represent a first step into postgraduate research. $\mathrm{PhDs}$ in Aotearoa are similar in structure to those offered in the United Kingdom: supervised independent research towards the completion of a thesis, with coursework seldom required. All universities offer contestable scholarship support from internal funding, and some scholarships are also offered through external research funding schemes, including the Marsden Fund, the Endeavour Fund, or the National Science Challenges. Because the scholarships are contestable, not all postgraduate students receive scholarships. These scholarships typically encompass payment of university fees (if applicable) as well as a contribution to living costs and any other support, e.g. to attend conferences or pay for research costs. In this paper, we use the term 'scholarship' throughout, but our discussion is limited to the living costs portion (usually called the 'stipend').

While presented as linear, in practice the postgraduate research landscape is increasingly complex and fractured, and postgraduate student scholarships provide a pinch point that sits at the intersection of many persistent issues. Financial precarity among students and researchers has become an increasingly urgent issue over past decades, with the massification of higher education and increases in student debt (Cassuto, 2015), the expansion of the 'gig economy' within higher education (Acker \& Haque, 2015; France et al., 2019), and rising costs of living (Consumers Price Index: September 2021 Quarter, 2021). Overlaying these developments are questions about the purpose and future of the research sector and workforce, including the potential for postgraduate research pathways to address persistent inequities within the sector (Naepi et al., 2017, 2019; Theodore et al., 2017).

Within this complex terrain, we argue that there is a vital equity dimension that needs to be brought to the fore: current student scholarships have the potential to limit who can realistically complete a postgraduate research 
degree. This paper provides much-needed evidence that postgraduate student scholarships are inadequate: they do not reflect the increased living costs and are not aligned with Minimum Wage increases. Further, the length of scholarship awards often falls short of the median time it takes to complete a graduate degree. This data provides persuasive evidence of the urgent need to lift the value and length of scholarships in line with increasing living costs. While we focus on equity, it is important to acknowledge there may also be implications for recruitment. We make comparisons between scholarship payments and the minimum wage to demonstrate their insufficiency, but people considering postgraduate study will likely make their decision based on comparison with what they could earn in full-time employment on a graduate wage.

In presenting this evidence, at times we consciously employ a language of 'investment', mirroring the logic used in academia to justify low scholarships, so we can demonstrate the shortcomings of this logic. We do so cautiously, recognising that such use risks further embedding and reinforcing neoliberal ways of thinking. As authors, we fundamentally oppose the neoliberal and managerial logics that structure, commodify, and marketise education, while being used as a justification to suppress wages. The title of this paper recognises the neoliberal understanding of education as a private good, a framing that has come to define much of the debate about postgraduate student scholarships. Much like a business, if you have no money you are expected to provide 'sweat equity' - to invest time and energy through work, as part of a cost-sharing relationship, to earn any personal benefit or profit. The response to calls for increased scholarships so far can be understood in these terms: universities provide the qualification and in return postgraduates provide the sweat - they do the work. Students with fewer financial means must supplement their income, compromising academic performance, reducing extra-curricular opportunities, risking burnout, and embedding existing inequities. The status-quo of low scholarships, supplemented by postgraduate 'sweat', excludes people from participating in postgraduate education, preventing them and their communities from realising the public benefits that such an education can produce.

\section{Context}

Scholarships sit at the intersection of multiple debates about the value of postgraduate research, which reflect wider shifts and contradictions within the higher education sector. It is clear, for example, that a $\mathrm{PhD}$ is no longer simply a mechanism for preparing one for a career in academia. The academic job market is saturated, leaving many early career researchers in fragmented and casual contracts for extended periods (Acker \& Haque, 2017; Oldfield et al., 2021; Rao et al., 2021; Spina et al., 2020). In some cases, key research institutions have argued that there is a "mismatch between the relatively narrow skills" of $\mathrm{PhD}$ graduates and the "skills needed in employment roles" that would enable successful careers "of value to New Zealand" (Royal Society Te Apārangi, 2020, p. 22), implying that a $\mathrm{PhD}$ also inadequately prepares postgraduate researchers for a career outside academia. Yet post graduate research is nevertheless valuable to universities and the wider research sector as research outputs, commoditised to stimulate the knowledge economy: the work of postgraduate researchers are included in productivity metrics like publications per million dollars spent (Ministry of Business, Innovation \& Employment, 2021). Moreover, postgraduate research is increasingly positioned as an important site to address wider societal equity commitments, as highlighted in 
discussion documents like Te Apārangi Royal Society's Early Career Researchers in Aotearoa: Safeguarding and strengthening opportunity after COVID-19 (2020). Although often overlooked, postgraduate research can produce material benefits in and of itself - particularly when embedded in (and led by) communities and attuned to their needs (Halse \& Mowbray, 2011).

Many of the tensions within the conceptualization of postgraduate research are rooted in neoliberal shifts in higher education in the 1980s. This period instigated a shift towards education as a commodity and individual investment, while maintaining some language about education as a public good. Alongside increasingly corporate management and branding of public services (Boston et al., 1996; Roper, 2018), structural shifts in university funding models saw universities shift away from exclusive, well-supported degree programmes where government funding kept tuition low and living allowances relatively universal, to a model that increased access by passing significant costs on to students (McLaughlin, 2003). The 1988 Hawke report advocated for a shift towards seeing higher education as a personal 'investment' with increased personal benefits which justified pushing costs onto individualised private citizens and away from the public purse (Hawke, 1988). To increase access to university without significantly increasing government spending, the Labour Government of the late 1980s abolished free fees for tertiary education, with the subsequent National Government of the 1990s introducing a student loan scheme and student allowances for students under 25 based on parental income (McLaughlin, 2003).

With these 'cost-sharing' reforms, postgraduate students saw increases in tuition fees, as well as an associated rise in student debt. These issues were brought to a head with the removal of the postgraduate student allowance in 2013 by the National-led Government. In justifying these reforms, the Ministry of Education noted the "value of postgraduate tertiary education" in terms of "social and economic benefits", but also framed postgraduate study as a matter of individual investment, noting that "masters graduates earn more than bachelor graduates" and therefore "expected student loan repayment times are shorter on average for postgraduate borrowers than for other borrowers" (Education and Workforce Committee, 2019). Yet the logic of personal investment - that students pay for education in exchange for presumed subsequent benefits—obfuscates processes of 'lean reproduction' and exploitation that can underpin postgraduate study (Roper, 2018; Welch, 2015). Particularly for PhD researchers, the tertiary workforce is increasingly characterised by precarious short-term employment, competition with colleagues and unequal pay as university management attempts to produce ever more with less (Berg et al., 2016; Green et al., 2020). Student debt is also at unprecedented levels, with the removal of postgraduate allowances further amplifying reliance on student loans as well as other forms of debt (Nissen et al., 2019; Sin et al., 2018). While many Doctoral graduates move into a variety of jobs outside of academia, this transition is often fraught and involves extended periods of fragmented and precarious work, while also often repaying significant debt (Acker \& Haque, 2017; Spina et al., 2020).

Studies have sought to explore the human costs of the financial conditions of graduate students. In a study of Otago University doctoral students, Cornwall et al. (2019) identify how financial strain is interwoven with other stressors in the first two years of candidature, which had a deleterious impact on students' wellbeing and 
performance. Their research showed that many students juggled employment, in addition to their full-time studies, to meet their monthly financial obligations, regardless of whether they received a scholarship. These demands of employment together with the personal demands of family and care work left many students with time-related stress and guilt about allowing job demands to take time away from their study. Some students also connected their financial constraints to a sense of isolation, for instance making it difficult to see family. In addition, both international and domestic students expressed financial worries about maintaining personal finances once scholarship funding finished, especially given uncertainty about the PhD structure and timely completion (Cornwall et al., 2019). This analysis resonates with other studies internationally that inadequate funding can be a hurdle to successful graduate student completion (Acker \& Haque, 2015; Larivière, 2013; Yusuf et al., 2020).

There are vital equity issues embedded in questions of financial strain on postgraduate students. For instance, Acker and Haque (2015) remind us of the many students who do not have the benefit of "financial cushioning" to enable them to pursue their postgraduate study unencumbered by debt and worry. There are also potential flow-on effects. Inequity and exclusion are persistent issues within New Zealand's research sector, despite commitments from the government and universities to value diversity and honour their obligations to equity under te Tiriti o Waitangi. Māori and Pacific scholars can experience systemic structural disadvantage and racism in universities, including the day-to-day reality of feeling isolated and the devaluing of Māori and Pacific knowledge, which can lead to the exclusion of Māori and Pacific bodies from universities (Kidman \& Chu, 2019; McAllister et al., 2020; Naepi et al., 2019). Research by McAllister et al. (2019) and Naepi (2019) on the current numbers of Māori and Pacific academics show severe underrepresentation of Māori and Pacific scholars in New Zealand's eight universities. Māori and Pacific comprise $16.5 \%$ and $7.5 \%$ respectively of the total population of Aotearoa, and yet comprise $4.8 \%$ and $1.7 \%$ respectively of academics. Naepi et al. (2019) have examined the period following a PhD for Māori and Pacific scholars. They identify a chronic under-representation of Māori and Pacific staff in both fixedterm contracts and permanent positions, suggesting that the pipeline into academia for Māori and Pacific scholars is fundamentally broken. Yet as the authors note, the idea of a pipeline alone is inadequate, and instead situate the experiences of $\mathrm{PhD}$ scholars within a wider context of navigating intersecting storms of racism, sexism, neoliberalism and neocolonialism, within the foundational whiteness of universities (Naepi et al., 2019, p. 153).

In New Zealand, fewer women enter the post-degree academic career pipeline than men and even once they do their work in academia is undervalued. Women, whose research career trajectories otherwise resemble men's in terms of research performance, are promoted more slowly (Walker et al., 2020) and have smaller incomes, resulting in a lifetime gender pay gap of $\sim \mathrm{NZ} \$ 400,000$ (Brower \& James, 2020). This means that the financial strain experienced by women as postgraduate students does not result in equitable outcomes in terms of academic opportunity, promotion, and pay. This situation is exacerbated globally by new managerialism in academia, which promotes precarity with gendered consequences (Steinpórsdóttir et al., 2019). There is no available data on the participation of people with disabilities in the New Zealand academy, but research in other countries shows that they are significantly underrepresented in postgraduate study, even compared to participation in undergraduate study (Booksh \& Madsen, 2018). Academic spaces can be particularly contributors to poor mental health, with low pay 
and precarity being significant factors (Horton \& Tucker, 2014). LGBTQIA+ scholars, particularly transgender scholars, have also been shown overseas to have more precarious and stressful existences in academic (and associated) spaces (Bonner-Thompson et al., 2021; Cech \& Waidzunas, 2021). For all these groups, financial stress during postgraduate study represents an additional barrier to academic participation.

\section{Methods}

There is currently a paucity of papers that explore inequities in scholarship values and how they have changed over time. Here, we have collated data about the value and tenure of scholarships from each of New Zealand's eight universities. All scholarships are tax-free. We present data on the value and tenure of PhD, Masters and Summer scholarships. We ask three questions of the data:

1) how has the value of scholarships changed over time?

2) is there a mismatch between the time it takes to complete a PhD and the length of PhD scholarships?; and

3) how does the living cost contribution of the average doctoral scholarship compare to the Minimum Wage and the Living Wage?

A request for scholarship data was sent to each individual university in July 2021. Universities are not individually named in the data we present as we felt that anonymity would increase their willingness to contribute data. We requested three sets of data: 1) the value and duration of Summer, Masters and Doctoral scholarships from 2000-2020, 2) the length of scholarships and whether fees were included, and 3) the length of time to complete a $\mathrm{PhD}$ broken down by ethnicity and subject area. Doctoral scholarships and $\mathrm{PhD}$ completion data includes both Doctor of Philosophy and Doctor of Education. Our request was discussed at a Universities New Zealand (UNZ) meeting and UNZ then took it upon themselves to collate and provide the data request. UNZ acquired data for PhD completions through the IDI (Integrated Data Infrastructure). The IDI is a large, research database which houses deidentified data about people and households. ${ }^{1}$ Information on requirements attached to doctoral scholarships was obtained from University regulations published on their respective websites in October 2021 and presented in Table $2 .^{2}$ Where restrictions on the amount of paid work were specified on a per annum basis in university documents, we divided by 52 weeks to calculate the average hours allowed per week.

Some universities were unable to provide the full temporal data set we requested due to historical data not being recorded. Data for Summer scholarships was particularly patchy, with one university not providing any data despite offering Summer scholarships. Limited scholarship data was provided as a range of minimum and maximum values, rather than a single value. This variation and range are presented in Figure 1, and we present averages only in

\footnotetext{
${ }^{1}$ The results in Figure 2 in this paper are not official statistics. They have been created for research purposes from the Integrated Data Infrastructure (IDI), managed by Statistics New Zealand.

${ }^{2}$ As this paper was being prepared for submission, the University of Canterbury raised its PhD stipend to $\$ 28,000$ p.a. plus tuition fees. This increase is not reflected in this paper and, while welcome, does not materially change the status quo or sufficiently address the inequity issues raised here.
} 
Figure S1. Additionally, we are aware that individual researchers occasionally top-up $\mathrm{PhD}$ scholarships, our data does not account for this and it is unknown how widespread this practice is. $\mathrm{PhD}$ completion data obtained through the IDI was based on EFTS (Equivalent Full-Time Student) and excluded suspensions. The median EFTS provided in the data abstract for full-time students was then divided by 12 to calculate an approximate duration of PhDs.

\section{Results}

\section{PhD Scholarships}

The average PhD scholarship value, which are tax-free, increased steadily from 2000-2010, increasing from $\$ 14,000$ to $\$ 24,476$ respectively (Fig.1). However, from 2011 to 2019, the average value of $\mathrm{PhD}$ scholarships remained stagnant. Over this period the highest and lowest scholarship values both changed by less than $\$ 1,000$. There was also large variation in scholarship values among universities (Fig. 1; Fig. S1). For example, in 2020, the largest PhD scholarship was $\$ 32,369$ and the smallest was only $\$ 21,000$ (Fig. S1). In 2014, the Minimum Wage (value after tax) exceeded the average value of PhD scholarships by $\$ 364$ (Fig. 1) and this gap has continued to increase over time. In 2019, the average PhD scholarship was \$5,417 less than the Minimum Wage and \$11,238 less than the Living Wage (Table 1).

All $\mathrm{PhD}$ scholarships are three years in length. At one university, however, recipients have, for the past 15 years, been able to apply for a six-month extension on their scholarship. Most $\mathrm{PhD}$ scholarships include paying tuition fees, on top of living costs. One university only began including fees in 2019 (data not shown).

\section{Table 1}

Annual Living Wage, Minimum Wage, and average PhD scholarship in 2019. The wage figures are given after tax and ACC, to compare directly with the tax-free scholarships.

\begin{tabular}{|c|c|c|}
\hline Living Wage & Minimum Wage & Average PhD scholarship \\
\hline$\$ 36,662$ & $\$ 30,841$ & $\$ 25,424$ \\
\hline
\end{tabular}

\section{Masters scholarships}

Masters scholarships have persistently been below the Minimum Wage, with the exception of one university in 2003 only (Fig. 1). The average value of Masters scholarships increased from 2000 to 2008, but stagnated between 2008 to 2018. Interestingly, the average value of Masters scholarships has decreased in the past 5 years due to some universities introducing scholarships of lower values (Fig. 1). The maximum Masters scholarship value has remained at $\$ 15,000$ from 2003 to 2020 (Fig. 1). The difference between the average Masters scholarship and the Minimum Wage in 2020 was $\$ 21,129.65$ (Fig. 1). In 2020, the minimum Masters scholarship offered was $\$ 5,500$ (Fig. 1).

All Masters scholarships are one year in length. Two out of eight universities did not include fees in their 
scholarships. For a single year, one university offered Masters students with disabilities a scholarship with a twoyear tenure, but subsequently ceased offering this arrangement (data not presented).

\section{Summer scholarships}

Although there is some variation among universities, the value of Summer scholarships has remained persistently low in the past eighteen years (Fig. 1; Fig. S1). The average value varied from $\$ 4,000$ in 2002 to $\$ 6,000$ in 2020 (Fig. 1). Summer scholarships are usually for 10 weeks of full-time work.

\section{PhD completions}

The median number of years to complete a $\mathrm{PhD}$ persistently exceeds the length of the three-year $\mathrm{PhD}$ scholarships regardless of the field study, by at least one year (Fig. 2). The median number of years was highest in the Social Sciences and Management at 4.75 years and lowest in Engineering and Technology and the Natural Sciences at 4 years (Fig. 2).

\section{Restrictions on doctoral scholarships}

Only three of the eight universities in New Zealand include compulsory student service fees or levies in their doctoral scholarships. Doctoral researchers at the remaining five must pay compulsory annual fees ranging from $\$ 610.00$ to $\$ 1,017.60$ (depending on the institution and campus; Table 2) in order to maintain full-time enrolment and access to their scholarship income.

Payment of doctoral scholarships are always contingent on full-time study, or pro-rated for part-time study where necessary. As such, recipients must agree to apply themselves to their studies full-time. Only three institutions specify an hourly expectation for full-time doctoral study. Victoria University of Wellington (VUW) and Auckland University of Technology (AUT) specify that a recipient must work on their research for at least 35 hours per week (Table 2). Massey University specifies that students are expected to engage in 40-50 hours of study per week (Table 2).

Many institutions allow recipients to take reasonable holiday leave on an annual basis without it affecting their entitlement. No New Zealand university, however, formally stipulates a recipient's entitlement to annual, parental, bereavement, or sick leave. Every university, except the University of Canterbury (UC), places explicit restrictions on the hours a recipient may work in addition to their research. Across these institutions scholars are limited to approximately 10-12 hours of additional paid work per week, with some institutions specifying a weekly limit and others an annual limit of 500-600 hours work within a calendar year. Such work is often subject to approval of a scholarship committee (Table 2).

Most universities place restrictions on co-tenure of their doctoral scholarships with other awards. In general, if a recipient receives other approved scholarships their university provided doctoral scholarship will begin to be attenuated once if it exceeds a specified amount. Most institutions allow a recipient to receive either an 
additional $30 \%$ or $50 \%$ of their scholarship value from another award before their entitlement is reduced. Massey allows co-tenure up to an additional $\$ 25,000$; Lincoln caps recipient's income from awards and scholarships at $\$ 35,000$ total. None of the New Zealand university generic doctoral scholarships impose conditions on a doctoral researcher's intellectual property (IP) — this generally resides with the researcher.

\section{Table 2}

Scholarships included fees, extra costs to recipients, expected working hours, and restrictions on paid work for each university in 2021. Costs to recipients are given at the 2022 rates, except for the University of Otago for which the

\begin{tabular}{|c|c|c|c|c|c|c|}
\hline University & Stipend & $\begin{array}{l}\text { Tuition fees } \\
\text { included }\end{array}$ & $\begin{array}{l}\text { Student Services } \\
\text { Levy included }\end{array}$ & $\begin{array}{l}\text { Expected hours } \\
\text { worked p.w. }\end{array}$ & $\begin{array}{l}\text { Restrictions on } \\
\text { paid work p.w. }\end{array}$ & $\begin{array}{l}\text { Part-time } \\
\text { arrangement }\end{array}$ \\
\hline $\begin{array}{l}\text { Auckland University } \\
\text { of Technology }\end{array}$ & $\$ 25,000$ p.a. & Yes & Yes & At least 35 hours & $<12$ hours & Unavailable \\
\hline Lincoln University & $\$ 28,000$ p.a. & Yes & No: $\$ 850$ p.a. & $\begin{array}{l}\text { "devote his or } \\
\text { her whole time } \\
\text { to study" }\end{array}$ & $<10$ hours & Unavailable \\
\hline Massey University & $\$ 25,000$ p.a. & Yes & Yes & 40-50 hours & $<10$ hours & $\begin{array}{l}\$ 15,00 \text { p.a. For } \\
<=60 \text { months }\end{array}$ \\
\hline $\begin{array}{l}\text { University of } \\
\text { Auckland }\end{array}$ & $\begin{array}{l}\$ 28,500 \text { p.a. }+ \\
\text { annual cost of living } \\
\text { adjustment }\end{array}$ & Yes & Yes & Full-time & $<10$ hours & Pro-rated \\
\hline $\begin{array}{l}\text { University of } \\
\text { Canterbury }\end{array}$ & $\$ 21,000-\$ 26,000$ p.a. & Yes & No: $\$ 892.80$ p.a. & Full-time & No information & Pro-rated \\
\hline University of Otago & $\$ 27,000$ p.a. & Yes & No: $\$ 879$ p.a. & Full-time & $<10$ hours & Pro-rated \\
\hline $\begin{array}{l}\text { University of } \\
\text { Waikato }\end{array}$ & $\$ 25,000$ p.a. & Yes & Yes & Full-time & $<10$ hours & Pro-rated \\
\hline $\begin{array}{l}\text { Victoria University } \\
\text { of Wellington }\end{array}$ & $\$ 27,500$ p.a. & Yes & No: $\$ 1,017.60$ p.a. & $\begin{array}{l}\text { At least } 35 \text { hours } \\
\text { p.w. }\end{array}$ & $<12$ hours & Pro-rated \\
\hline
\end{tabular}

2021 rates for the Dunedin Campus are the most up-to-date available. ${ }^{3}$ p. $a=$ per annum, $p . w=$ per week

\footnotetext{
${ }^{3}$ All data in Table 2 is taken from the most recent doctoral scholarship regulations published by each respective university on its website (AUT Doctoral Scholarship Regulations and Conditions, 2020; Lincoln University Doctoral Scholarship Regulations, n.d.; Massey University Doctoral Scholarship Regulations, 2021; Regulations and Notes for the University of Otago Postgraduate Research Scholarships, n.d.; Scholarships and Awards - Massey University, n.d.; Scholarships: Lincoln University, n.d.; University of Auckland Doctoral Scholarship Regulations, 2020; University of Canterbury Doctoral Scholarships
} 


\section{Discussion}

Our findings have highlighted the inadequacies of research scholarships in Aotearoa. Not only is there a significant and growing gap between scholarships and Minimum/Living Wage, but they are also insufficient in terms of the time that it takes to complete a research degree. The neoliberal logics that currently guide our tertiary sector provide the justification for paying postgraduate researchers below-living wage. The cost-sharing approach to postgraduate research, where universities provide financial support while scholars provide sweat equity, is skewed in favour of universities, who have kept their financial contribution low relative to inflation and cost of living such that it is now incommensurate with the skilled labour of researchers. The understanding, by governments and universities, that tertiary education is both a public and private good, paid for in a cost-sharing relationship, hides the reality of living on a subsistence-scholarship that simultaneously restricts earning power through contractual limitations on hours worked. In this discussion, we consider the potential implications of this growing gap for developing a more inclusive and equitable research sector.

The gap between graduate scholarships and the cost of living raises concerns about who is able to engage in and complete postgraduate studies. There has been growing interest in developing supportive 'pipelines' into research to help address persistent inequities within the sector (e.g. Naepi et al., 2019). Disengagement from postgraduate studies is, however, evident in the decrease of progression onto postgraduate studies from 2006-2019, where the progression to a higher degree within two years from Honours/Postgraduate Diploma decreased from $24 \%$ to $18 \%$ and from $7 \%$ to $6 \%$ for Masters to a higher degree among domestic students (Rates of Progression to Further Study after Graduating, 2021). The number of students transitioning to postgraduate studies began to dropoff in 2014, a year after postgraduate living allowances were cancelled. The data on rates of progression to higher postgraduate degrees suggests that the government's justification for continuing to delay the reinstatement of postgraduate allowances (because of total increases in enrolments) is faulty. These enrolments do not indicate an overall increase in the rate of participation. These concerns are especially apparent for Māori and Pacific scholars. While there are higher or similar rates of progression to graduate studies for Māori and Pacific communities, there are lower completion rates for Māori and Pacific students in bachelor or higher qualifications (Naepi et al., 2021). There is a lack of data on Masters and PhD scholars that would add the much needed in-depth understanding of how equity operates within the progression and completion rates, and how low scholarship values contribute to the ongoing under-serving of Māori and Pacific communities.

The gap between postgraduate scholarships and the cost of living also suggests a hidden toll for many of those who do engage in postgraduate research. With no allowance, the gap between scholarships and living costs needs to be met through other means. This resonates with other studies that have highlighted the juggling of multiple sources of financial support (Acker \& Haque, 2015; Cornwall et al., 2019; Larivière, 2013). Those with the capacity

Regulations, 2020; University of Waikato Doctoral Scholarship Regulations 2021, n.d.; Wellington Doctoral Scholarship Regulations | Victoria University of Wellington, 2021). Full bibliographic details are included in the references section. 
to work in addition to their studies can make up some of the shortfalls; however, taking on the maximum allowed paid work (typically 10-12 hours per week) in addition to full-time study results in a workload in excess 40 hours per week which is nevertheless unlikely to pay commensurately with a living wage. Remaining shortfalls are likely met through increased student loans (up to their caps), private debt and/or family contributions, if available. While there is a general increase in earnings for those who complete graduate degrees, these are field dependent (i.e. not all postgraduates benefit from increased earnings) and arguably not significant enough to justify high levels of debt or years of financial hardship. For instance, overall, the increase in earnings between a $\mathrm{PhD}$ and Masters 11 years after completing a degree is only $\$ 11,535$ per annum, which arguably does not justify the increased debt taken on in fees and living costs. This costing does not take into account ethnic pay gaps which are shown to exist at a Bachelors degree or higher (Scott, 2021).

There is also the issue of the length of scholarships. The higher education sector values doctoral completion rates, as evident in the Research Degree component of the Tertiary Education Commission's Performance-Based Research Funding (PBRF) which makes up 25\% of the total yearly \$321 million fund (Performance-Based Research Fund, 2021). This funding is calculated on a three-year rolling average of "research-based postgraduate degree completions, weighted by research volume, relative costs of the subject areas, and ethnicity and completions in Te Reo" (Performance-Based Research Fund, 2021). This creates a time-boundary for $\mathrm{PhDs}$, as institutions can only claim up to 4 EFTS per doctorate per student, with any study exceeding that reported as "non-funded delivery" (The Tertiary Education Commission, 2021, p. 144). Yet these incentives to complete $\mathrm{PhDs}$ within four years are only met by Engineering and Technology and the Natural Sciences, indicating that there is a disconnect between the length of time it takes to complete a $\mathrm{PhD}$ and funding incentives. While scholarship deadlines of three years are frequently described as a 'carrot' to encourage students to complete, completions across all fields of study are consistently at least a year longer, leaving students to attempt to make up this financial shortfall. There is an important debate to have about the length of $\mathrm{PhD}$ stipends and the incentives and restrictions these provide for students and for supervisors. The concerns about equity we raise in this paper should be centred in these discussions.

Together, these shortfalls in scholarships mean that postgraduates who are not independently wealthy must accept sub-Minimum Wage incomes and a consequently reduced quality of life to engage in postgraduate study. The excessive workload necessary to meet the basic cost of living materially impacts the quality of research, as postgraduate students have less time to focus on their research, to rest, to think, and to engage in university life. It contributes to a culture of overwork and prevents working postgraduate students from accessing the (mostly unpaid) opportunities necessary to cultivate a research career. This requirement of overwork and underpayment systematically disadvantages those with disabilities, caring or familial responsibilities, and those without access to independent wealth who need a reliable, liveable income. Postgraduates required to supplement their income through additional work may need to transition to part-time study to meet expenses, creating additional years of income lost compared to other work. The high cost of accommodation also means students are likely limited, for extended periods of time, to cheaper, poor-quality accommodation, often involving significant commutes to city campuses, with associated demands on their time and potentially detrimental effects to their health and wellbeing. 
These disadvantages are exacerbated for Māori and Pacific scholars, who on average earn less than their Pākehā counterparts, are less likely to have access to familial wealth, and have been subject to colonial brutality and disempowerment (see Barber \& Naepi, 2020; Pacific Pay Gap Inquiry, n.d.; Salesa, 2017; Schulze \& Green, 2017). These systemic factors exclude people from participating in postgraduate education, preventing them (and their communities) from realising the public benefits that such an education can produce.

There are, however, relatively straightforward steps that could be taken to make a big difference for postgraduate students:

1. Raise Summer, Masters and $\mathrm{PhD}$ scholarships to match the Living Wage

2. Extend award tenure of $\mathrm{PhD}$ scholarships and national funding levers so scholarships reflect the actual time it takes to complete a postgraduate degree, including recognition of students with disabilities

3. Reinstitute the postgraduate living allowance

As a result of emerging researcher advocacy, some of these actions are already underway. A promising example in Aotearoa is the raising of scholarships by the Cancer Society to $\$ 40,000$ per year, plus $\$ 10,000$ per year in tuition fees, and a tikanga contribution of \$10,000 across the course of the award (Māori Cancer Researcher (Early Career) Awards 2021, 2021). A more ambitious and comprehensive approach to addressing these issues could follow international precedent and treat $\mathrm{PhD}$ scholars as fixed-term employees for the duration of their studies. This would give scholars access to a wage that appropriately reflects their skill and expertise, leave allowances, professional development opportunities, and equal access to a union which could advocate for their working conditions (Survey on the Structure of the Doctorates across Europe, n.d.). Related options could involve restructuring scholarships to account for housing cost and location, childcare, and other cost of living factors, even extending to providing affordable housing close to campus. Such approaches would aim to improve the educational experience and create a less inequitable environment for post-graduates by providing an immersive environment where they live and work on campus, with realistic living costs accounted for, without the need for supplementary employment.

By continuing to offer scholarships below Living Wage for highly skilled, home-grown researchers with the capability to work on world-leading research in Aotearoa, we devalue the knowledge that we develop and produce. At this point, it needs to be asked: who would —or is able to — sign up for a postgraduate degree with little income and low career prospects? It is increasingly urgent that we understand how universities have justified the levelling out of graduate scholarships so that we can challenge what is contributing to a decrease in graduate progression, inequity in our universities and growing frustration from graduate students about their 'stolen wages' (Cahill, 2021a, 2021b; University of Sydney Casuals Network, 2020). 


\section{Acknowledgements}

Firstly, we would like to thank Dr Joseph Chen and the members of the University of Auckland who have led the way in collating evidence to push for change and increases in postgraduate scholarships. Thank you to Chrystal O'Connor and Caitlin Hyde for their leadership and advocacy in this space. We also acknowledge Dr Caroline Daley (University of Auckland) and Chris Whelan (Universities NZ) for their assistance in collating data. We thank Andrew Sporle, Dr Nicola Gaston and Miriam Walker for their constructive feedback. This paper is a mihi to all emerging researchers in Aotearoa, especially postgraduate students - who are at the forefront of research and who deserve to be paid a living wage. 


\section{References}

Acker, S., \& Haque, E. (2015). The struggle to make sense of doctoral study. Higher Education Research \& Development, 34(2), 229-241. https://doi.org/10.1080/07294360.2014.956699

Acker, S., \& Haque, E. (2017). Left Out in the Academic Field: Doctoral Graduates Deal with a Decade of Disappearing Jobs. Canadian Journal of Higher Education, 47(3), 101-119. https://doi.org/10.47678/cjhe.v47i3.187951

AUT Doctoral Scholarship Regulations and Conditions. (2020). Auckland University of Technology. https://www.aut.ac.nz/_data/assets/pdf_file/0007/154492/AUT_Doctoral_2020May_Regulations_Conditions.pdf

Barber, S., \& Naepi, S. (2020). Sociology in a crisis: Covid-19 and the colonial politics of knowledge production in Aotearoa New Zealand. Journal of Sociology, 56(4), 693-703. https://doi.org/10.1177/1440783320939679

Berg, L. D., Huijbens, E. H., \& Larsen, H. G. (2016). Producing anxiety in the neoliberal university. The Canadian Geographer / Le Géographe Canadien, 60(2), 168-180. https://doi.org/10.1111/cag.12261

Bonner-Thompson, C., Mearns, G., \& Hopkins, P. (2021). Transgender negotiations of precarity: Contested spaces of higher education. The Geographical Journal, 187(3), 227-239. https://doi.org/10.1111/geoj.12384

Booksh, K. S., \& Madsen, L. D. (2018). Academic pipeline for scientists with disabilities. MRS Bulletin, 43(8), 625632. https://doi.org/10.1557/mrs.2018.194

Boston, J., Martin, J., Pallot, J., \& Walsh, P. (1996). Public Management: The New Zealand Model. Oxford University Press.

Brower, A., \& James, A. (2020). Research performance and age explain less than half of the gender pay gap in New Zealand universities. PLOS ONE, 15(1), e0226392. https://doi.org/10.1371/journal.pone.0226392

Cahill, D. (2021a, October 17). Wage theft is Australian universities' dirty little secret. Australian Financial Review. https://www.afr.com/work-and-careers/education/wage-theft-is-australian-universities-dirty-little-secret20211015-p590eg

Cahill, D. (2021b, October 27). Wage theft and casual work are built into university business models. The Conversation. http://theconversation.com/wage-theft-and-casual-work-are-built-into-university-businessmodels-147555

Cassuto, L. (2015). The Graduate School Mess: What Caused It and How We Can Fix It. Harvard University Press. 
Cech, E. A., \& Waidzunas, T. J. (2021). Systemic inequalities for LGBTQ professionals in STEM. Science Advances, 7(3). https://doi.org/10.1126/sciadv.abe0933

Consumers price index: September 2021 quarter. (2021, October 18). Stats NZ. https://www.stats.govt.nz/information-releases/consumers-price-index-september-2021-quarter

Cornwall, J., Mayland, E. C., van der Meer, J., Spronken-Smith, R. A., Tustin, C., \& Blyth, P. (2019). Stressors in early-stage doctoral students. Studies in Continuing Education, 41(3), 363-380. https://doi.org/10.1080/0158037X.2018.1534821

Early Career Researcher Forum Early Career Researchers in Aotearoa: Safeguarding and strengthening opportunity after COVID-19. (2020). Te Apārangi Royal Society Early Career Researcher Forum. https://www.royalsociety.org.nz/assets/Aotearoa-ECRs-Post-COVID-August-2020.pdf

Education and Workforce Committee. (2019). Petition of James Ranstead for New Zealand Union of Students' Associations: Restore the postgraduate student allowance now Report of the Education and Workforce Committee (p. 5). Education and Workforce Committee. https://www.parliament.nz/resource/enNZ/SCR_91244/10bf6af2538cf5eb43e924b87f46c441a8678dd8

France, A., Pukepuke, T., Cowie, L., Mayeda, D., \& Chetty, M. (2019). 'Imagined futures' in the navigation and management of uncertainty for young women in Aotearoa, New Zealand. Journal of Sociology, 55(4), 654-669. https://doi.org/10.1177/1440783319888281

Green, W., Anderson, V., Tait, K., \& Tran, L. T. (2020). Precarity, fear and hope: Reflecting and imagining in higher education during a global pandemic. Higher Education Research \& Development, 39(7), 13091312. https://doi.org/10.1080/07294360.2020.1826029

Guesgen, M. (2021, October 11). The unsteady, underpaid reality of life as a New Zealand scientist. The Spinoff. https://thespinoff.co.nz/science/11-10-2021/the-unsteady-underpaid-reality-of-life-as-a-new-zealandscientist/

Halse, C., \& Mowbray, S. (2011). The impact of the doctorate. Studies in Higher Education, 36(5), 513-525. https://doi.org/10.1080/03075079.2011.594590

Hawke, G. R. (1988). Report of the working group on post compulsory education and training 1988.

Hopkins, J. (2020, October 18). Calls to Increase PhD Stipend Rejected by UoA. http://craccum.co.nz/news/reporting/calls-to-increase-phd-stipend-rejected-by-uoa/ 
Horton, J., \& Tucker, F. (2014). Disabilities in academic workplaces: Experiences of human and physical geographers. Transactions of the Institute of British Geographers, 39(1), 76-89. https://doi.org/10.1111/tran.12009

Kidman, J., \& Chu, C. (2019). 'We're not the hottest ethnicity': Pacific scholars and the cultural politics of New Zealand universities. Globalisation, Societies and Education, 17(4), 489-499. https://doi.org/10.1080/14767724.2018.1561247

Larivière, V. (2013). PhD students' excellence scholarships and their relationship with research productivity, scientific impact, and degree completion. Canadian Journal of Higher Education / Revue Canadienne d'enseignement Supérieur, 43(2), 15.

Lincoln University Doctoral Scholarship Regulations. (n.d.). Lincoln University. Retrieved 19 October 2021, from https://www.lincoln.ac.nz/assets/Uploads/LU-Doctoral-Scholarship-Regulations.pdf

Māori Cancer Researcher (Early Career) Awards 2021. (2021, August 11). Cancer Society NZ. https://www.cancer.org.nz/supporting-you/cancer-research/research-grants/

Massey University Doctoral Scholarship Regulations. (2021). Massey University. https://boomproduction.blob.core.windows.net/public-content/files/AE3770E5-2B72-42E3-A8DAE8CA580F29DC

McAllister, T. G., Kidman, J., Rowley, O., \& Theodore, R. F. (2019). Why isn’t my professor Māori? A snapshot of the academic workforce in New Zealand universities. MAI Journal: A New Zealand Journal of Indigenous Scholarship, 8(2). https://doi.org/10.20507/MAIJournal.2019.8.2.10

McAllister, T. G., Kokaua, J., Naepi, S., Kidman, J., \& Theodore, R. (2020). Glass Ceilings in New Zealand Universities: Inequities in Māori and Pacific promotions and earnings. MAI Journal: A New Zealand Journal of Indigenous Scholarship, 9(3). https://doi.org/10.20507/MAIJournal.2020.9.3.8

McLaughlin, M. (2003). Tertiary Education Policy in New Zealand. Ian Axford (New Zealand) Fellowships in Public Policy. https://www.fulbright.org.nz/wp-content/uploads/2011/12/axford2002_mclaughlin.pdf

Ministry of Business, Innovation \& Employment. (2021). The Research, Science and Innovation Report-2021. Ministry of Business, Innovation \& Employment. https://mbienz.shinyapps.io/research-scienceinnovation-report/pdf/research-science-and-innovation-system-performance-report-2021.pdf

Morton, J. (2021, September 28). 'Flatly embarrassing': 700 scientists call for pay hike for Marsden students. NZ Herald. https://www.nzherald.co.nz/nz/flatly-embarrassing-700-scientists-call-for-pay-hike-for-marsdenstudents/MJCYX6ZAMNPP3EASKNULFLRQ5E/ 
Naepi, S. (2019). Why isn’t my professor Pasifika? A snapshot of the academic workforce in New Zealand universities. MAI Journal: A New Zealand Journal of Indigenous Scholarship, 8(2). https://doi.org/10.20507/MAIJournal.2019.8.2.9

Naepi, S. (2021, May 18). We are looking into the costs of going to university to open up a national discussion! [Tweet]. @SereanaNaepi. https://twitter.com/SereanaNaepi/status/1394493630149062656

Naepi, S., McAllister, T. G., Thomsen, P., Leenen-Young, M., Walker, L. A., McAllister, A. L., Theodore, R., Kidman, J., \& Suaaliia, T. (2019). The Pakaru 'Pipeline': Māori and Pasifika Pathways within the Academy. The New Zealand Annual Review of Education, 24, 142-159. https://doi.org/10.26686/nzaroe.v24i0.6338

Naepi, S., Stein, S., Ahenakew, C., \& Andreotti, V. de O. (2017). A Cartography of Higher Education: Attempts at Inclusion and Insights from Pasifika Scholarship in Aotearoa New Zealand. In C. Reid \& J. Major (Eds.), Global Teaching: Southern Perspectives on Teachers Working with Diversity (pp. 81-99). Palgrave Macmillan US. https://doi.org/10.1057/978-1-137-52526-0_5

Naepi, S., Wilson, E., Lagos, S., Manuela, S., McAllister, T. G., Kidman, J., Theodore, R., \& Kokaua, J. (2021). Where are we now? Patterns of Māori and Pasifika enrolment in the Natural and Physical Science and Society and Culture fields in Aotearoa New Zealand. Higher Education Research \& Development, 40(1), 90-103. https://doi.org/10.1080/07294360.2020.1857345

Nissen, S., Hayward, B., \& McManus, R. (2019). Student debt and wellbeing: A research agenda. Kōtuitui: New Zealand Journal of Social Sciences Online, 14(2), 245-256. https://doi.org/10.1080/1177083X.2019.1614635

O'Connor, C., \& Hyde, C. (2021). Increase the PhD stipend to minimum wage. Change.Org. Retrieved 27 October 2021, from https://www.change.org/p/new-zealand-s-universities-increase-the-phd-stipend-to-minimumwage

Oldfield, L. D., Roy, R., Simpson, A. B., Jolliffe Simpson, A. D., \& Salter, L. A. (2021). Academic Activism in the Wake of a Pandemic. International Perspectives in Psychology. https://doi.org/10.1027/2157$3891 / \mathrm{a} 000027$

Pacific Pay Gap Inquiry. (n.d.). Pacific Pay Gap Inquiry. Retrieved 2 November 2021, from https://pacificpaygap.hrc.co.nz

Performance-Based Research Fund. (2021, August 24). Tertiary Education Commission Te Amorangi Mātauranga Matua. https://www.tec.govt.nz/funding/funding-and-performance/funding/fund-finder/performancebased-research-fund/ 
Rao, N., Hosein, A., \& Raaper, R. (2021). Doctoral students navigating the borderlands of academic teaching in an era of precarity. Teaching in Higher Education, 26(3), 454-470. https://doi.org/10.1080/13562517.2021.1892058

Rates of progression to further study after graduating. (2021, July). Educationcounts.Govt.Nz; Ministry of Education. https://www.educationcounts.govt.nz/statistics/tertiary-participation

Regulations and notes for the University of Otago postgraduate research scholarships. (n.d.). University of Otago. Retrieved 19 October 2021, from https://www.otago.ac.nz/graduateresearch/scholarships/otago013798.pdf

Roper, B. (2018). Neoliberalism's war on New Zealand's universities. New Zealand Sociology, 33(2), 9-39.

Royal Society Te Apārangi. (2020, November 30). The Research Workforce of Aotearoa. https://www.royalsociety.org.nz/assets/Research-Workforce-of-Aotearoa-NZ-briefing-paper-andoutcomes-Feb-2021.pdf

Salesa, D. (2017). Island Time: New Zealand's Pacific Futures (1st edition). Bridget Williams Books.

Scholarships and awards-Massey University. (n.d.). Massey University. Retrieved 19 October 2021, from https://www.massey.ac.nz/massey/admission/scholarships-bursaries-awards/scholarship-bursaryaward_home.cfm?id=83B45FEA-2E17-48C0-B717-CA5F15B27B6E

Scholarships: Lincoln University. (n.d.). Lincoln University. Retrieved 19 October 2021, from https://www.lincoln.ac.nz/study/scholarships/

Schulze, H., \& Green, S. (2017). Change Agenda: Income Equity for Māori. BERL. http://www.maorifutures.co.nz/wp-content/uploads/2019/11/Income-Equity-for-Maori.pdf

Scott, D. (2021). Education, income and earnings_-With updates for 2020. Ministry of Education. https://www.educationcounts.govt.nz/_data/assets/pdf_file/0008/208268/Education-income-andearnings-2020-Report.pdf

Simpson, A. B. (2021, September 24). Have you been precariously employed in any of NZs Unis in the last year? [Tweet]. @aimeebsimpson.https://twitter.com/aimeebsimpson/status/1441179018384998413

Sin, I., Maré, D., \& Apatov, E. (2018). How did removing student allowances for postgraduate study affect students' choices? 
Spina, N., Harris, J., Bailey, S., \& Goff, M. (2020). 'Making It' as a Contract Researcher: A Pragmatic Look at Precarious Work. CRC Press. https://www.crcpress.com/Making-It-as-a-Contract-Researcher-APragmatic-Look-at-Precarious-Work/Spina-Harris-Bailey-Goff/p/book/9781138362598

Steinpórsdóttir, F. S., Brorsen Smidt, T., Pétursdóttir, G. M., Einarsdóttir, P., \& Le Feuvre, N. (2019). New managerialism in the academy: Gender bias and precarity. Gender, Work \& Organization, 26(2), 124 139. https://doi.org/10.1111/gwao.12286

Survey on the structure of the doctorates across Europe. (n.d.). Eurodoc. Retrieved 2 November 2021, from http://eurodoc.net/doctoral-training-wg/doctorates-across-europe

Tertiary Education Commission. (2021). Funding Conditions Catalogue 2021. Tertiary Education Commission Te Amorangi Mātauranga Matua. https://www.tec.govt.nz/assets/Forms-templates-and-guides/FundingConditions-Catalogue-2021-v2.pdf

Theodore, R., Taumoepeau, M., Kokaua, J., Tustin, K., Gollop, M., Taylor, N., Hunter, J., Kiro, C., \& Poulton, R. (2017). Equity in New Zealand university graduate outcomes: Māori and Pacific graduates. Higher Education Research and Development. https://doi.org/10.1080/07294360.2017.1344198

Time for leadership in science. (2021, August 4). Otago Daily Times Online News. https://www.odt.co.nz/opinion/editorial/time-leadership-science

University of Auckland Doctoral Scholarship Regulations. (2020). University of Auckland. https://cdn.auckland.ac.nz/assets/Scholarships/regulations/university-of-auckland-doctoralscholarship.pdf

University of Canterbury Doctoral Scholarships Regulations. (2020). University of Canterbury. https://www.canterbury.ac.nz/scholarshipsforms/regulations/UC_Doctoral_Scholarship.pdf

University of Sydney Casuals Network. (2020). Over-worked and Worked Over: Casual Academics Bear the Costs of COVID-19. https://usydcasuals.files.wordpress.com/2020/07/survey-report-2.pdf

University of Waikato Doctoral Scholarship Regulations 2021. (n.d.). University of Waikato. Retrieved 28 June 2021, from https://www.waikato.ac.nz/_data/assets/pdf_file/0019/501058/University-of-WaikatoDoctoral-Scholarship-Regulations-2021.pdf

Walker, L., Sin, I., Macinnis-Ng, C., Hannah, K., \& McAllister, T. (2020). Where to from Here? Women Remain Absent from Senior Academic Positions at Aotearoa New Zealand's Universities. Education Sciences, 10(152), 152. https://doi.org/10.3390/educsci10060152 
Welch, N. (2015). Educating for austerity: Social reproduction in the corporate university. International Socialist Review, 98. https://isreview.org/issue/98/educating-austerity/index.html

Wellington Doctoral Scholarship Regulations | Victoria University of Wellington. (2021, October 5). Victoria University of Wellington. https://www.wgtn.ac.nz/scholarships/current/wellington-doctoral-scholarships

Yusuf, J.-E. (Wie), Saitgalina, M., \& Chapman, D. W. (2020). Work-life balance and well-being of graduate students. Journal of Public Affairs Education, 26(4), 458-483.

https://doi.org/10.1080/15236803.2020.1771990 


\section{Figures}

Fig. 1 The average value (dollars in the hand) of Doctoral, Masters and Summer Scholarships at New Zealand's eight Universities from 2000 to 2020. Shaded areas represent maximum and minimum values. Blue lines represent the Minimum Wage after tax

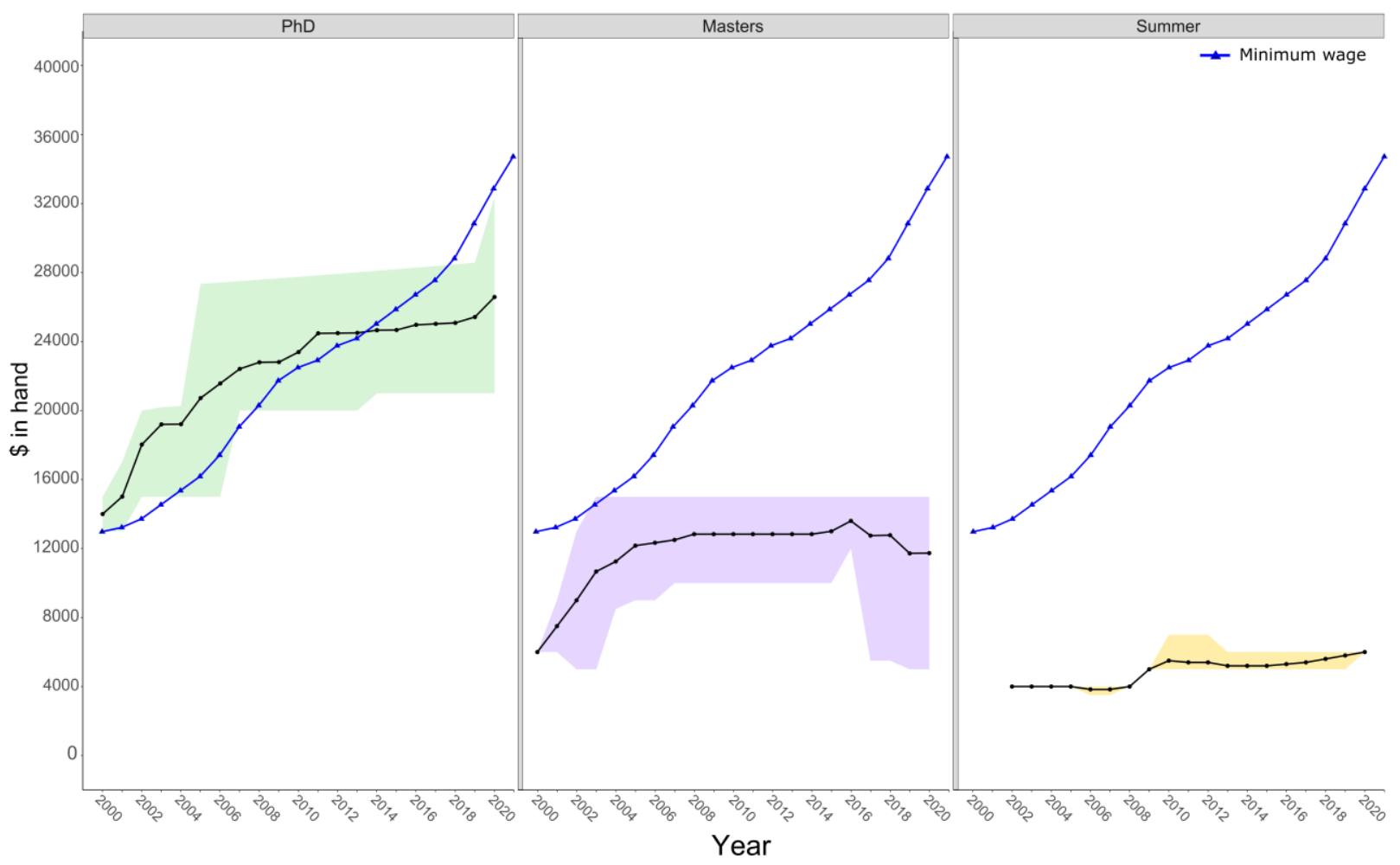


Fig. 2 Median number of years for non-Māori to complete a PhD full-time from 2000-2020 by field of study

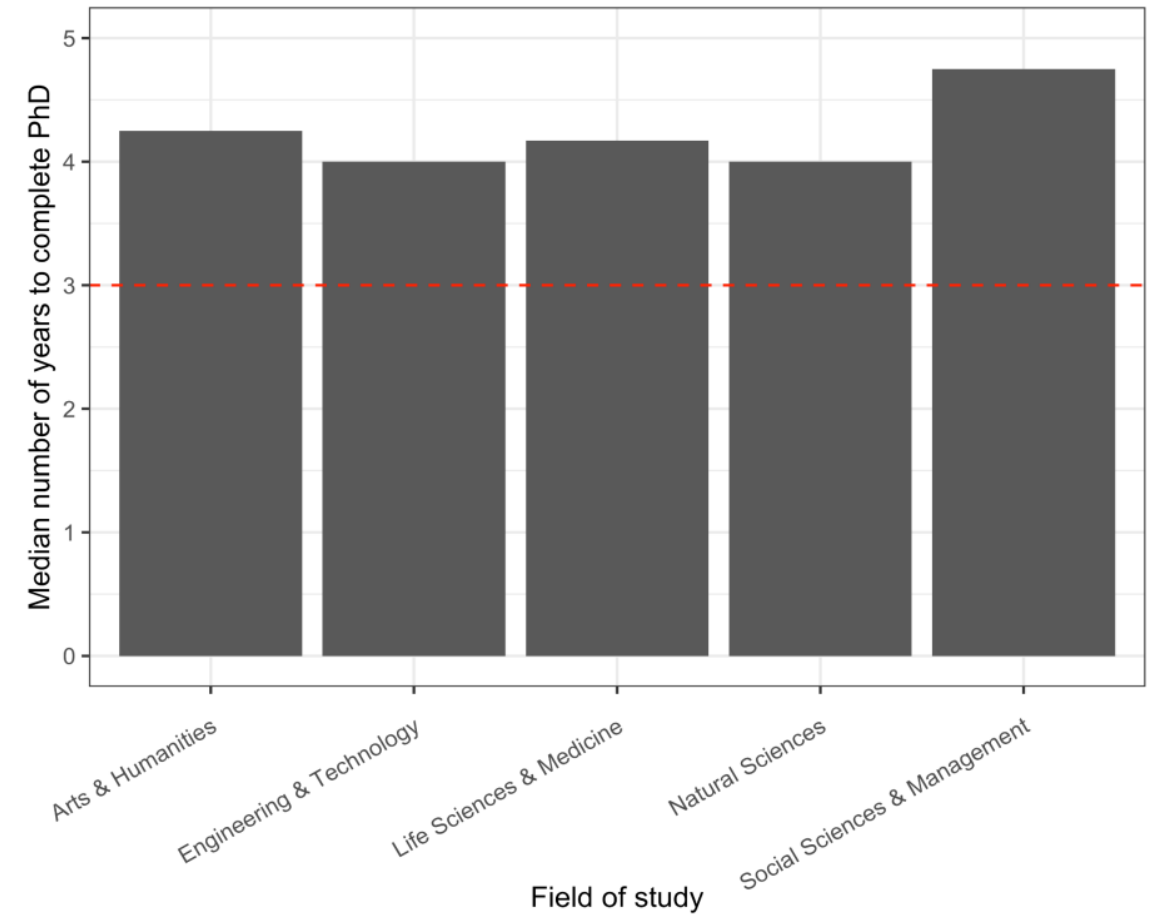




\section{Supplementary material}

Fig. S1 The value of $\mathrm{PhD}$, Masters and Summer scholarship compared to Minimum Wage at each University from 2000 to 2020. Note: Summer scholarships are usually for a period of 10 weeks. University B and C provided a range for Masters scholarships and both values are plotted.

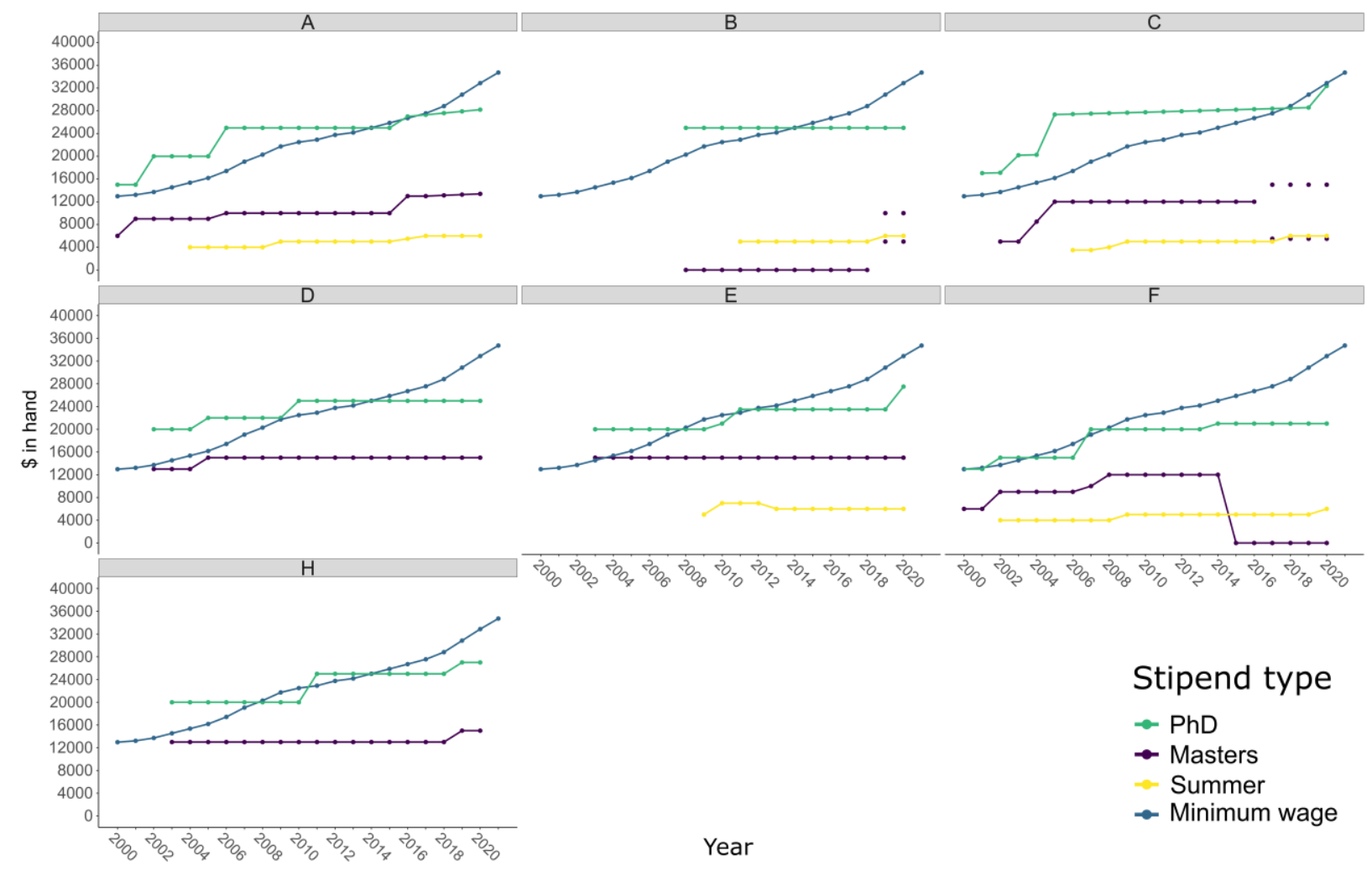

